\title{
Assessment of the health care system functioning in Poland in light of the analysis of the indicators of the hospital emergency department (ED) and primary health care (PHC) - proposals for systemic solutions
}

\author{
KATARZYNA SZWAMEL ${ }^{1, A-G}$, DONATA KURPAS ${ }^{2, \text { c-E }}$
}

ORCID ID: 0000-0001-8186-9979

${ }^{1}$ Medical School in Opole, Poland

${ }^{2}$ Department of Family Medicine, Wrocław Medical University, Poland

A - Study Design, B - Data Collection, C - Statistical Analysis, D - Data Interpretation, E - Manuscript Preparation, F - Literature Search, G - Funds Collection

Summary Background. In the last three decades, in developed countries, the number of patients reporting to hospital emergency departments has dramatically increased. The number of visits to EDs can be an important indicator of the quality of primary health care. Objectives. To analyse: 1) the frequency of admissions to EDs, 2) the type and number of medical procedures performed in EDs, and 3) the type and number of services provided by PHC in the Kedzierzyn-Kozle district.

Material and methods. A retrospective analysis of the statistical data regarding services provided by PHC in the Kedzierzyn-Kozle district within the National Health Fund (NHF) and data from the hospital emergency department in Kedzierzyn-Kozle (Opole Province, Poland).

Results. The results showed an annual increase in the number of hospitalisations $(13,815-2012,14,192-2013,15,123-2014)$ and the number of medical procedures performed in the ED (mainly those from I-III categories), as well as the low rate of admission from the ED to ICU (Department of Anaesthesiology and Intensive Care). There was an increase in the overall number of consultations given by a primary health care doctor and the total number of healthcare services provided at night and during holidays.

Conclusions. Reducing the number of non-urgent visits to EDs can be achieved by making efforts to meet the needs of patients at the level of primary health care, in particular through better coordination of services provided by EDs and PHC and better motivation of primary care doctors to perform the role of gatekeeper to the health care system.

Key words: delivery of health care, comprehensive health care, professional practice gaps, primary health care, emergency service, hospital.

Szwamel K, Kurpas D. Assessment of the health care system functioning in Poland in light of the analysis of the indicators of the hospital emergency department (ED) and primary health care (PHC) - proposals for systemic solutions. Fam Med Prim Care Rev 2019; 21(2): 164-173, doi: https://doi.org/10.5114/fmpcr.2019.84553.

\section{Background}

The last three decades have seen a dramatic increase in the number of patients reporting in developed countries to hospital emergency departments (EDs) [1-5]. The low level of satisfaction with the services provided by primary health care staff, difficulties in making an appointment to a primary health care facility, lack of trust and very long waiting time for a visit may lead to reporting to hospital emergency departments in non-urgent situations [6]. The number of visits to EDs can be an important indicator of the quality of primary health care [1].

ED overcrowding is a situation in which the performance of due functions by emergency departments is difficult because of the excessive number of patients awaiting health assessment, examination, diagnosis, treatment or discharge in relation to the efficiency of the staff employed [7, 8]. This often leads to the prolongation of the time patients wait for services provided by the ED and subsequently results in lowering their satisfaction with medical care [9]. ED crowding may also be connected with poorer performance and adverse clinical outcomes, including increased mortality [10]. For example, in the study conducted by Kulstad et al. (2009), ED overcrowding was associated with delays in percutaneous coronary intervention for acute myocardial infarction [11]. Sun et al. (2012) showed that patients who were admitted on days of ED overcrowding experienced a $5 \%$ greater risk of inpatient death, $0.8 \%$ longer hospital length of stay and $1 \%$ increase in costs per admission [12].

According to the report entitled Emergency Care Services: trends, drivers and interventions to manage the demand concerning health services provided by Emergency Departments in 21 OECD countries (Organization for Economic Co-operation and Development), in 2011, there were 31 visits to EDs per 100 inhabitants on average. The highest number of visits (70 visits per 100 inhabitants) was recorded in Portugal. Over 40 visits per 100 inhabitants were reported in such countries as the USA, Spain, Chile, Canada and Greece. It was calculated that in countries like the Czech Republic, Germany, New Zealand, the Netherlands, Switzerland and Poland, there were less than 20 visits per 100 inhabitants [13]. The research carried out by the Health Care Quality Monitoring Centre in Cracow in 223 EDs in Poland revealed that the average burden to the ED in Poland oscillated around the number of 16,000 patients per year. During one year, 6 EDs treated over 50,000 patients [14]. Even though it is true that the problem of the burden of Polish EDs is still much smaller in comparison to Western European countries or the USA, it is an important problem [13, 14].

The factors that result in excessive frequent visits to the ED include: loneliness, homelessness, alcoholism, the occurrence 
of mental illness (obsessive-compulsive disorder, personality disorders, depression, schizophrenia, addiction to psychoactive substances), chronic diseases, younger age (from 25-44 years) or old age (over 65 years), as well as living in close proximity to the ED [15-20].

ED overcrowding is partly due to the phenomenon of non-urgent visits [21]. These are visits to the ED when patients report health problems that do not cause a threat to their life and do not require immediate treatment; therefore, the decision to undertake medical care can be safely dismissed in time [22] or when a problem can be solved or the patient's needs can be met by outpatient care [23]. An international literature review performed by Durand et al. demonstrated that $4.8 \%$ to $90 \%$ of ED patients were potentially non-urgent cases, with a median of $32.1 \%$ [24]. In the Turkish study, the proportion of ED visits for non-urgent conditions was $23.4 \%$ [25]. Previous research showed a non-urgent character of $56 \%$ of visits in Belgium, $32 \%$ in Australia, $31 \%$ in Portugal, $25 \%$ in Canada, $20 \%$ in Italy, $12 \%$ to $30 \%$ in the US and $11.7 \%$ to $15 \%$ in England [2, 22, 26, 27]. In Polish EDs, $30 \%$ to $80 \%$ of patients were not eligible for services provided in these wards, as they were not in a state of immediate health risk [14, 28, 29].

Apart from non-urgent patients (non-invasive visits, inappropriate ED visits), elderly people are also responsible for the phenomenon of ED overcrowding [30]. In this group, ED reporting is related to multiple morbidities, functional limitations, falls, deprivation of needs, lack of care and support, as well as dementia, organic disorders, behavioural changes, aggression, depression, self-inflicted injuries, alcohol abuse, polypharmacy, urinary tract infections, exacerbating pain, malnutrition and the need to provide care in the last stage of life [2, 30, 31]. It has been proven that people aged 85 years and over have a 10 -fold greater chance of being hospitalised in the ED compared to those aged 20 to 40 years [32]. Eurostat data showed that the share of people aged 80 years or above in the EU-28's population is projected to more than double between 2017 and 2080, from $5.5 \%$ to $12.7 \%$ [33]. Taking into account the fact that in 2050, Poland will become one of the European countries with the most advanced aging of the population, we can expect that the problem of ED reporting in this group of patients may increase [34]. According to Azuma and Ohta, the concept of frailty may by introduced as an indicator of prognosis and applied in relation to the future of emergency medicine [35].

A high demand for ED services can be explained by the high expectations of society, both towards access and the level of health services, as well as the convenience and ease of access to the highly specialised services provided by emergency departments [14, 36-38]. The currently observed rapid medical and technological progress, along with the increasing medical specialisation and the manner in which health care is organised, jeopardise the quality and efficiency of health care and make clinical coordination difficult, as patients often observe an ever-expanding array of professionals in a variety of different settings $[38,39]$. Discontinuity of care undermines its effectiveness through misapplied or duplicative treatment. In this situation, primary care physicians lose opportunities to educate their patients about when it is appropriate to report to emergency departments and to learn about gaps in their own availability that may be unnecessarily overused by patients [40].

According to $\mathrm{McHale}$ et al., many non-urgent visits to EDs can be avoided by better patient and community care management by a team of professionals at the level of primary health care [23]. Given the above, the study assumed that both the number of patients admitted to the ED and the number of procedures performed in this department are growing year to year and that the majority of medical procedures performed in the emergency department are not associated with a sudden health risk and could be realised on an outpatient basis.

\section{Objectives}

The aim of the study was to analyse the benefits provided by PHC, the frequency of admissions to EDs, the type and number of medical procedures performed in the ED in the Kedzierzyn-Kozle district in the years 2012-2014, as well as to propose systemic solutions for the Polish healthcare system in light of the study results obtained.

\section{Material and methods}

This study involved a retrospective analysis of the statistical data from the years 2012-2014 regarding health services provided in the Kedzierzyn-Kozle district and data obtained from the Opole Department of the National Health Fund (NHF), as well as the data from the Asseco Medical Management Solutions computer system (AMMS) of the Hospital Emergency Department in Kedzierzyn-Kozle (Opolskie, Poland) from the years 2012-2014. The research covered the number of services provided by PHC in individual areas of activity, the type and number of procedures performed in the ED, the number of patients' admissions to the ED and the rate of the bed use at the ED. Percentages and rates of dynamics of changes were calculated for the years 2013/2012, 2014/2013 and 2014/2012. The "patients' flow indicator", determining how many patients used one hospital bed in a given time period, was also used. This is calculated as the ratio of the number of patients hospitalised and the number of beds. The research obtained the approval (No. KB-87/2016) of the Bioethics Committee of the Medical University in Wroclaw.

\section{Results}

The number of all patients hospitalised in the years 2012-2014 in the ED in Kedzierzyn-Kozle was 50,693. There was an annual increase in the number of hospitalisations, including 13,815 in 2012, 14,192 in 2013 and 15,123 in 2014. The patients' flow indicators in ED amounted to: 2,762.17 patients (2012), 2,802.50 patients (2013), 2,907.83 patients (2014).

After ED hospitalisation, some patients were referred to hospital wards for further treatment. ED patients most often continued treatment in the internal diseases unit ( $\mathrm{Me}=795$, min-max, 550- 985), orthopaedic ( $\mathrm{Me}=453$, min-max, 444-491), neurological ( $M e=423$, min-max, 390-433), geriatric (Me = 196, min-max, 192-209) and surgical department (Me $=198, \min -\max , 177-213)$. A relatively low admission rate was reported for patients transferred from the ED to ICU $(\mathrm{Me}=68$, min-max, 66-69). The median percentage of admissions from the ED to ICU was $2.55 \%$ of all admissions to hospital wards, with the percentage of admissions from the ED to ICU being constant at a level of $0.4 \%$ of all admissions to the ED in each year in the years 2012-2014.

In the analysed period, the number of medical procedures performed in the ED also increased. In 2013, the number of procedures was higher by 5,549 (7.47\%) than in 2012, and in 2014, higher by 9,921 (13.35\%) compared to 2012 (Table 1).

\begin{tabular}{|l|l|l|l|l|l|l|}
\hline \multicolumn{5}{|l|}{ Table 1. Number of medical procedures performed in the ED in the years 2012-2014 } \\
\hline Years 2012-2014 & Difference & Dynamics of changes \\
\hline Year 2012 & Year 2013 & Year 2014 & $\mathbf{2 0 1 3 - 2 0 1 2}$ & $\mathbf{2 0 1 4 - 2 0 1 2}$ & $\mathbf{2 0 1 3 / 2 0 1 2}$ & $\mathbf{2 0 1 4 / 2 0 1 2}$ \\
\hline 74,311 & 79,860 & 84,232 & 5,549 & 9,921 & $7.47 \%$ & $13.35 \%$ \\
\hline
\end{tabular}




\begin{tabular}{|c|c|c|c|c|c|c|c|c|c|c|c|c|c|c|c|c|c|c|c|c|c|c|c|c|}
\hline & $=$ & $\begin{array}{l}\tilde{N} \\
\text { nn }\end{array}$ & 苫 & ô & i & $\begin{array}{l}\tilde{y} \\
\dot{y}\end{array}$ & iे & $\begin{array}{l}\text { Sू } \\
\text { ने }\end{array}$ & 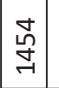 & 柔 & $\underset{\sim}{\sim}$ & $\underset{\exists}{ \pm}$ & \& & 弚 & $\begin{array}{l}\text { ने } \\
\text { की }\end{array}$ & 离 & N̂̃ & స్ & F & $\left|\begin{array}{l}\mathscr{0} \\
m\end{array}\right|$ & $\overrightarrow{\widehat{N}}$ & $\underset{\sim}{\sim}$ & & 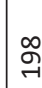 \\
\hline & 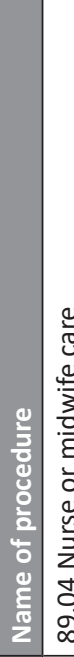 & 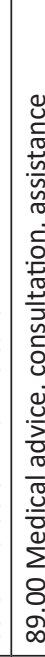 & 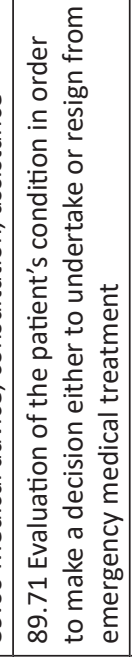 & 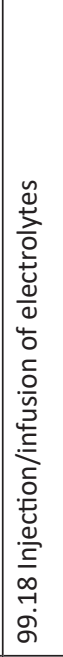 & 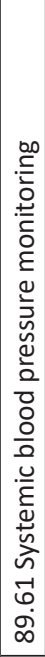 & 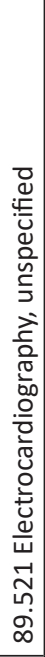 & 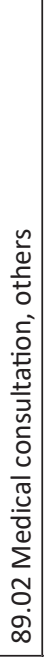 & 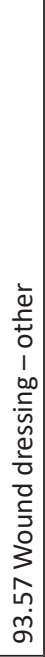 & 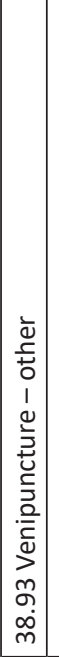 & 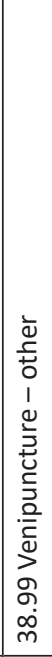 & 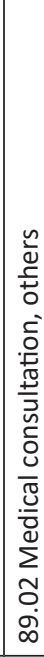 & 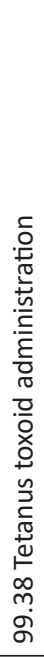 & 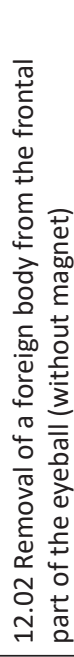 & 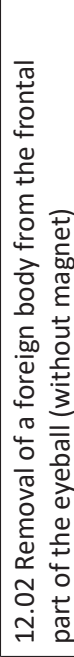 & 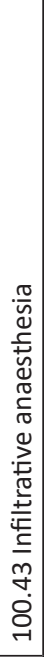 & 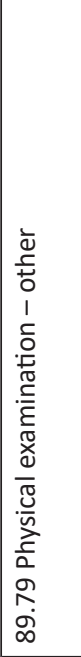 & 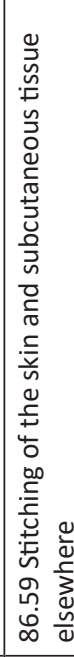 & 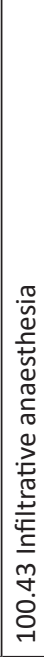 & 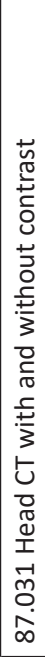 & 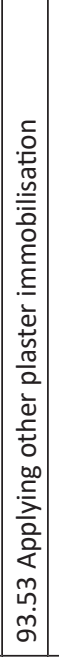 & 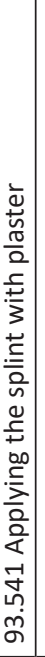 & 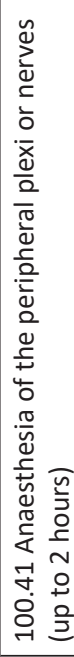 & 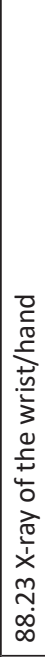 & \\
\hline & $=$ & 总 & 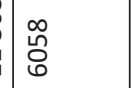 & 이 & 㟢 & 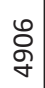 & 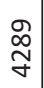 & 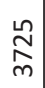 & $\mid \begin{array}{l}0 \\
0 \\
0\end{array}$ & 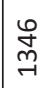 & $\underset{\sim}{\infty}$ & & & & ळ̆ & 10 & $\stackrel{\infty}{\curvearrowright}$ & 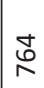 & ల్m & $\mid \begin{array}{l}5 \\
6\end{array}$ & 号 & f & 命 & 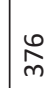 \\
\hline 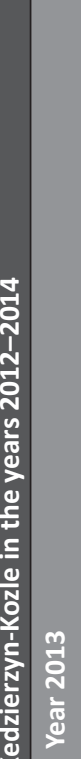 & 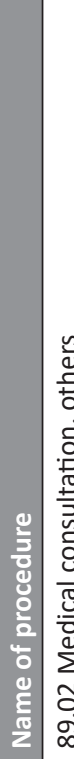 & 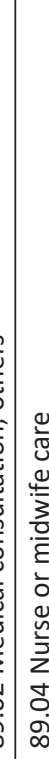 & 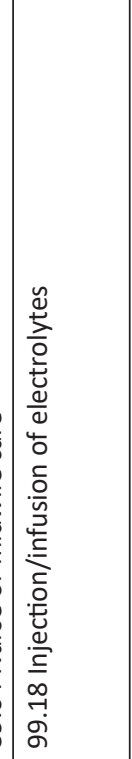 & 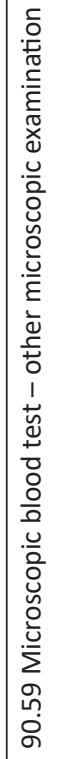 & 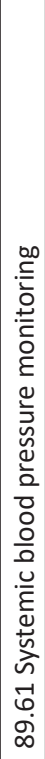 & 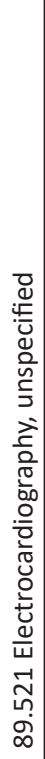 & 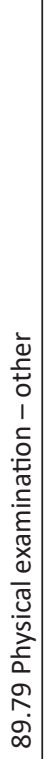 & 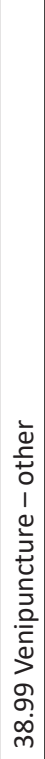 & 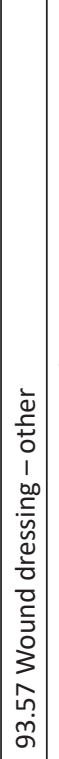 & 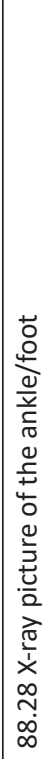 & 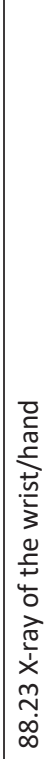 & 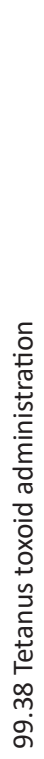 & 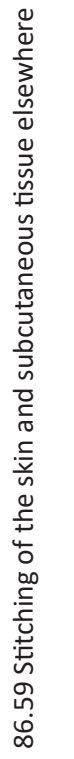 & 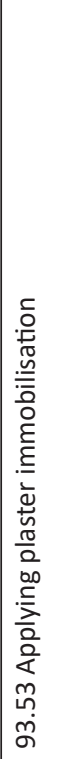 & 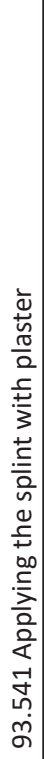 & 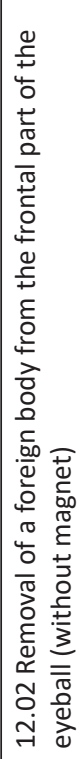 & 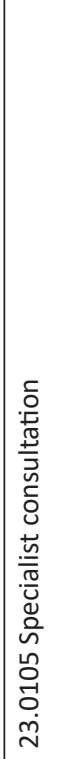 & 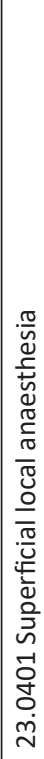 & 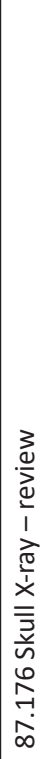 & 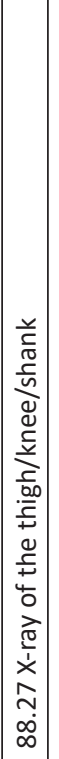 & 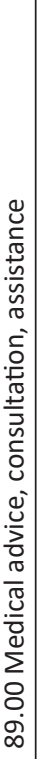 & 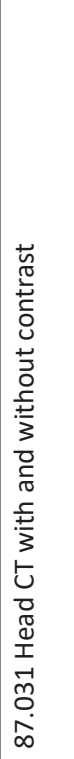 & 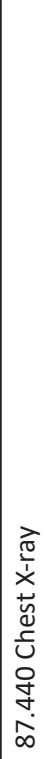 & \\
\hline
\end{tabular}

ֻ

ก

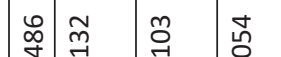

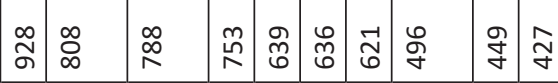

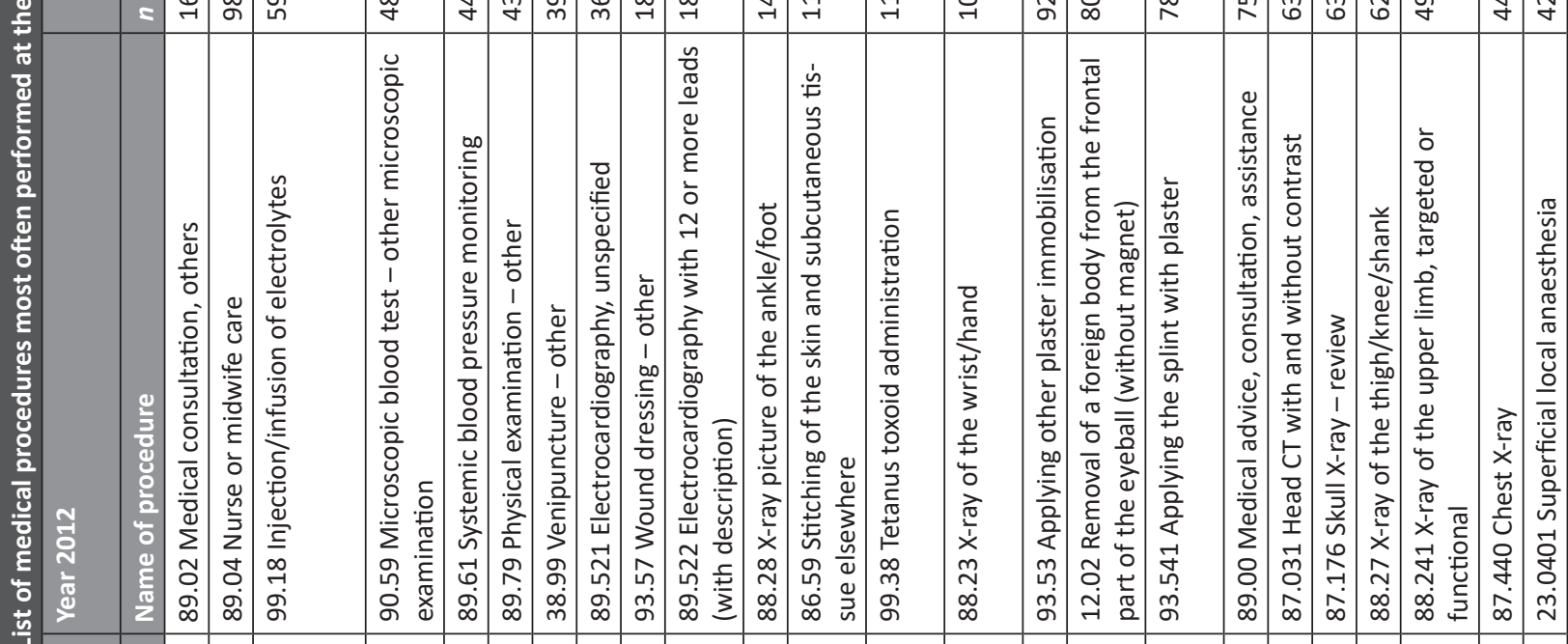




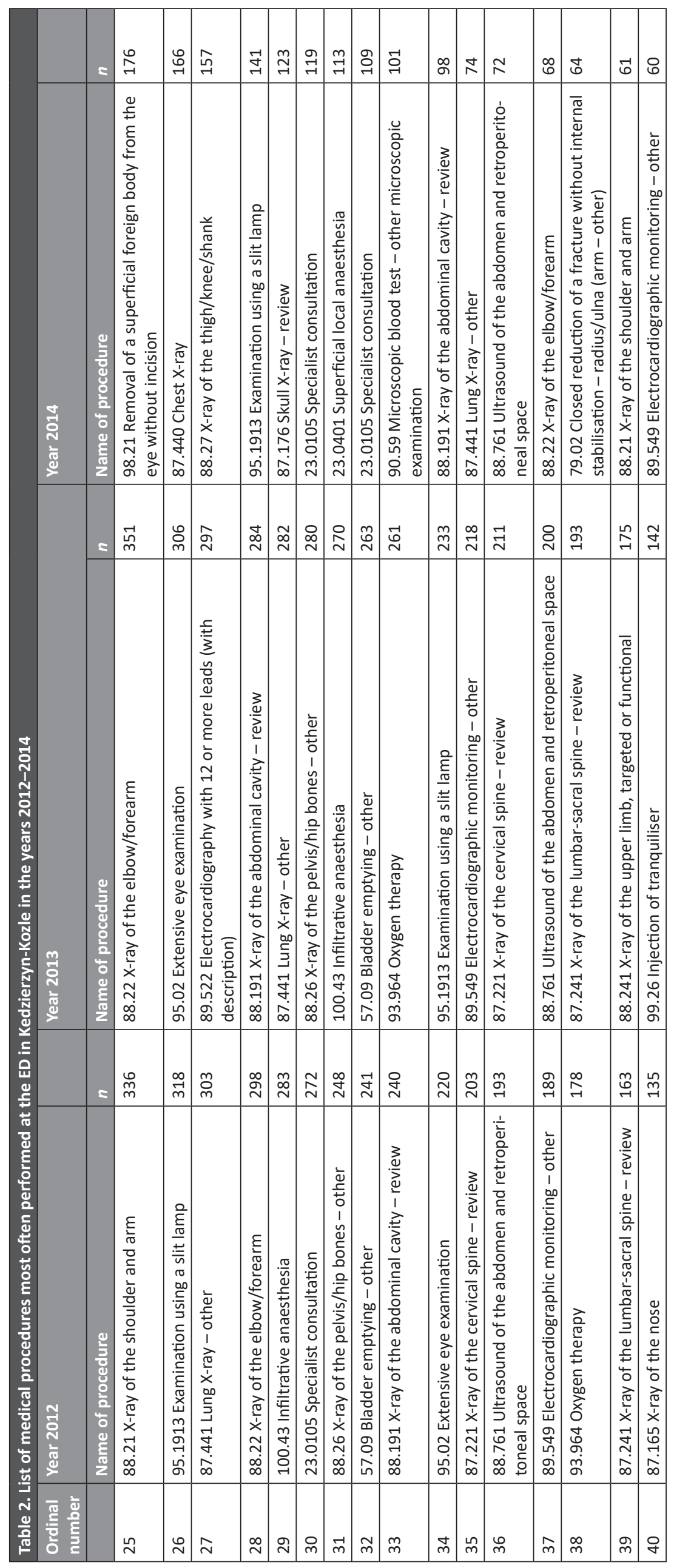


Throughout all these years, in addition to such procedures as medical consultation and care of a nurse or midwife, the most common procedures were: electrolyte injection/infusion, microscopic blood test, physical examination, systemic blood pressure monitoring, electrocardiography, venipuncture, dressing of a wound. Common procedures included: X-ray of the ankle/foot or wrist and hand, administration of tetanus toxoid, stitching of the skin and subcutaneous tissue, applying plaster immobilisation, removal of a foreign body from the frontal part of the eyeball (without a magnet) (Table 2).

As for the services provided by the PHC, the following were analysed: services provided by a primary care physician, nurse and school nurse, as well as healthcare services provided at night and during holidays.

In the period of the study, a total of $11,033,847$ services were provided by primary health care doctors in the Kedzierzyn-Kozle district $(3,621,703$ services in $2012,3,638,745$ in 2013 , $3,773,399$ in 2014). There was an increase in the total number of consultations given by the primary care physician - the number in 2013 was higher by $3.70 \%$ than in 2012, while in 2014, the number was higher by $4.19 \%$ than in 2012 . Year to year, there was an increase in the number of medical consultations given at the primary health care unit to patients for reasons other than diabetes and/or cardiovascular diseases (in 2013 - an increase by $3.38 \%$, and in 2014 - a rise by $5.01 \%$ ). In addition, in 2014 , the number of medical consultations provided to patients in connection with the treatment of diabetes and/or cardiovascular diseases decreased both in terms of the number of services provided at the patient's home (a decrease by $9.80 \%$ from 15,401 to 13,891 ) and at the primary health care unit (by $7.17 \%$ from 969,962 to 900,423 ). The number of medical consultations provided at the patient's home for reasons other than diabetes and/or cardiovascular diseases has also decreased - by $3.72 \%$ in the years 2012-2014.

The total number of services performed by the primary health care nurse was unchanged $(1,445,158-2012,1,372,684$ $-2013,1,448,460-2014)$. The number of patronage visits of the primary health care nurse in 2014 decreased by $27.94 \%$ compared to 2013 (from 1,571 to 1,132) and by $25.77 \%$ in comparison to 2012 (from 1,525 to 1,132). The number of other home visits of the nurse in 2014 fell by $2.12 \%$ compared to 2013 and marginally increased by $0.18 \%$ compared to 2012 . In addition, an analysis of the services provided by the primary health care nurse revealed an increase in the number of rehabilitation services (by 19.96\%), the number of injections and treatments carried out based on the order of the health insurance doctor (by $9.31 \%$ ) and the number of patients who, in the reporting period, underwent screening tests (by $11.68 \%$ ).

As for the coordination of services provided by the ED and PHC, certain school nurse services are also important, especially those provided in the field of emergency care and performed in children with chronic diseases. The number of emergency care services provided by these nurses to students in 2012 amounted to 53,509, in $2013-49,677$, and in $2014-50,634$; while the number of services and treatments performed in students with chronic diseases clearly showed an upward trend - in 2012 2,795, in 2013-3,941, and in $2014-4,121$.

Moreover, there was an increase in the total number of healthcare services provided at night and during holidays in 2014 - by $14.4 \%$ compared to 2013 (from 215,710 to 245,991) and by $3.55 \%$ in 2014 compared to 2012 (from 237,559 to $245,991)$. At that time, there was an increase in the number of outpatient medical consultations given at night and during holidays (by 22.98\% in 2014 compared to 2012, from 117,880 to 144,963 , and by $36.45 \%$ in 2014 compared to 2013 , from 106,242 to 144,963 ) and medical consultations at home (in 2014 an increase by $22.39 \%$ compared to 2012 , from 4,382 to 5,363 , and by $20.52 \%$ compared to 2013 , from 4,450 to 5,363 ). However, there was a decrease in the number of outpatient visits provided by nurses (by 19\% in 2014 compared to 2012, from 98,931 to 80,137 , and by $10.17 \%$ compared to 2013 , from 89,209 to 80,137 ) and services provided at home (by $23.89 \%$ in 2014 compared to 2012 , from 15,112 to 11,501 , and by $10.17 \%$ compared to 2013 , from 12,803 to 11,501 ).

\section{Discussion}

\section{Analysis of services provided by the ED and PHC}

In our study, a three-year follow-up showed, in addition to an increase in the number of ED hospitalisations, a year to year rise in the number of medical procedures performed in this ward. We also showed an increase in the general number of consultations given by a primary care physician, the number of certain services provided by a PHC nurse and school nurse and the total number of healthcare services provided at night and during holidays, as well as a decrease in the number of medical consultations given at a patient's home. It should be noted that statistics indicate a gradually decreasing number of inhabitants of the Kedzierzyn-Kozle district in the analysed period - in 2012 $-97,879$, in $2013-97,181$, and in $2014-96,715$ [41].

In the results of own research, it was shown that the patients' flow indicator in ED increased every year. Data from the Central Statistical Office (CSO) shows that the number of people using outpatient services has been steadily increasing in Poland in recent years. And so, in 2014, in the emergency rooms or Eds, medical aid was provided in an outpatient mode to 4.5 million people - i.e. about 200,000 more than in 2013 [42]. In 2015, this number amounted to 4.6 million people [43]. In 2016, it increased by 46 thousand people compared to 2015, and in 2017, it reached 4.8 million [44]. In turn, other CSO data shows an increase in the amount of outpatient advice - the total amount of medical advice given in Poland in the following years was 300 million (2012), 307.4 million (2013) and 311.8 million (2014). However, a relatively stable percentage of advice provided in the PHC was observed (it amounted to $52 \%$ of the total number of outpatient consultations - 2012, 52.4\% - 2013, and 52.3\% - 2014, respectively), while the percentage of advice provided in specialised care decreased (in year 2012 it amounted to $48 \%$, in $2013-47,6 \%$ and in $2014-36,6 \%$ of the total number of outpatient consultations) $[42,45,46]$. Probably one of the reasons for the increasing burden of ED patients is the difficult availability of specialist consultations at the level of outpatient care and many months of waiting for such services, while the patients' expectations regarding the scope of provided services are increasing $[47,48]$.

In view of the results received, an increase in the number of medical consultations provided to patients within the PHC in the area of the studied district should be considered ineffective given an increase in demand for lower-rated services provided by the ED over the same period of time. If primary health care physicians had the appropriate financial motivation to improve the quality of patient care and expand the range of their services, and if the patients were satisfied with these services, this would be reflected in a reduction of the number of ED admissions and the type of procedures performed in this department. Meanwhile, the analysis of the procedures, according to the codes, clearly showed that among the 40 treatments most frequently performed in the ED, there were no rescue procedures from higher categories, i.e. IV, V and VI (e.g. patient ventilation, cardioversion, pleural drainage, chest drainage, sedation and intensive supervision, manual resuscitation, endotracheal intubation, artificial respiration using a face mask or resuscitation mask, insertion of a catheter into the artery, using magnetic resonance for diagnostics, cardiopulmonary resuscitation in an intensive care unit or air transport, etc.). It was demonstrated that the procedures from categories I, II and III predominated in the analysed period. Most of these procedures can be performed in the outpatient clinic, e.g. electrolyte injection/infusion, blood 
microscopy, systemic blood pressure monitoring, electrocardiography, venipuncture, dressing of a wound, $\mathrm{X}$-ray of the ankle/ /foot or wrist/hand, administration of tetanus toxoid, stitching of the skin and subcutaneous tissue, applying plaster immobilisation. Although these activities are found in the catalogue of rescue procedures and each patient is a separate case requiring individual consideration, the fact that mainly procedures from lower categories are performed at the ED and a small percentage of admissions from the ED to ICU (it accounted for $0.4 \%$ of all admissions to the ED in each year in the years 2012-2014 and was low) may indirectly indicate the burden on the ED with non-urgent cases. For comparison, in Norway, the percentage of admissions from the ED to ICU is fluctuating around 1\% [4], and in Denmark, around 1.6\% [49]. In the USA, the percentage of admissions from the ED to ICU accounted for $1.5 \%$ of all ED admissions in 2011 [50], and 1.1\% in 2015 [51].

\section{Proposals for systemic solutions}

One of the constructive and rational proposals to solve the problem of non-urgent ED visits is to make efforts to strengthen primary health care. According to the report of 2017 entitled What is our primary health care and what we need, $64 \%$ of the respondents negatively assessed the functioning of PHC. Every second patient $(49 \%)$ claimed that his/her doctor was not motivated to work with the patients [52]. This may result from the method of financing primary health care, chiefly based on the capitation system, which does not encourage PHC workers to take full care over patients, thus "pushing them out" to outpatient specialist care and hospital wards, including the ED. Baranowski and Windak believe that the method of PHC funding based on the capitation rate not only does not encourage physicians to work more efficiently and to provide high quality care, but it is also not a fair way to reward doctors for their work. Moreover, the size of correctors of capitalization rates is not properly adjusted to patient care expenses [53]. Borek et al. demonstrated that the capitation rate mechanism as the only form of PHC financing did not have a beneficial impact on the degree of implementation and quality of preventive care tasks. The researchers proved that the mixed system of financing preventive PHC care (i.e. by means of the capitation rate and the fee for visit) was by far the best, as it had a positive influence both on the quantitative and qualitative parameters assessing the work of PHC staff. In the study cited, the authors showed that compared to doctors and nurses, whose work was financed on the basis of the capitation system, the midwife, as the only worker rewarded on the basis of the mixed system, was the most effective and the least-priced representative of the medical personnel, which was beneficial from the perspective of the payer. Physicians, who were paid based on the capitation rate system, implemented only $61 \%$ of the visits provided by the regulation, while the nurse $26 \%$ of the visits provided by the regulation. At the same time, the midwife, who was rewarded using the mixed system, provided prophylactic visits to over $90 \%$ of children. Borek et al. argue that it would be optimal to abandon the PHC capitation funding system in favour of the mixed system, which takes into account the per-visit rate and, preferably, the result (quality assessment parameters) [54].

Another interesting solution of PHC financing was introduced in Germany. In 2008, the first contract was signed between AOK Baden-Württemberg and the family doctors' association, circumventing national health funds and constructing the system of rewarding primary care physicians so as to encourage them to play the role of system gatekeeper. The doctor's salary contained several components, i.e. a basic lump sum independent of the number of contracts, then a lump sum depending on the number of contacts, quarterly allowance for the treatment of chronically ill patients dependent upon the number of contacts and an allowance depending upon the outcomes. Such a motivational rewarding method turned out to be beneficial, as by 2013 , the contracts with AOK were signed by another 3,500 doctors [55].

In order to reduce the number of ED visits, it is also important to seek solutions aimed at coordinating and integrating primary health care and hospital care, including the ED. Clinical coordination is considered a health policy priority, as its absence can lead to poor quality of care and inefficiency [39]. Care coordination is "the deliberate organisation of patient care activities between two or more participants involved in a patient's care to facilitate the appropriate delivery of health care services" [56]. The rationale for undertaking interventions aimed at coordinating and integrating patient and community care are, for example, the results of the Commonwealth Fund International Health Policy Survey of $2013(n=13,958)$. The researchers showed that patients who assessed the level of care coordination as low were more often hospitalised and more frequently reported to the ED in urgent and non-urgent situations compared to those highly evaluating the level of coordination [57]. The use of one common triage system for patients reporting to emergency departments on their own without a medical referral could be an example of activities undertaken to coordinate care between the ED and PHC. Depending on the results of triage, the patient would then go directly to the ED or would be referred to the PHC doctor. This solution was adopted in some regions of the Netherlands [58]. On the other hand, Rider et al. pointed out the need to coordinate activities between the ED and PHC, which, in practice, involves the need for communication between the ED physician and the primary care doctor during the discharge of the ED patient in order to optimise further patient care at the PHC level [59]. Communication and coordination can help emergency physicians as they formulate plans of care, particularly for patients with chronic illnesses who may have complex medical histories [40]. Doctors participating in the study conducted by Rider at al. reported varied expectations and multiple barriers to effective communication. In addition, emergency physicians preferred telephone contact synchronous to the encounter, whereas primary care physicians were in favour of using the electronic medical record asynchronous to the encounter. The researchers indicated a need to optimise technology for an effective transition of the information from the ED to the outpatient setting [59]. Primary care doctors and home health care providers play a crucial role in the coordination of care. In the future, primary health care doctors and family doctors should closely cooperate with the hospital, and the importance of their role should be more evident [35].

As mentioned in the introduction, the demographic aging of the population will gradually contribute to the growing burden on the ED concerning elderly people. It is necessary to look for constructive systemic solutions for this group of patients. They require comprehensive coverage of their needs, and after hospitalisation, they should be provided with adequate care at home or long-term care. Poor coordination between hospitals and facilities which are responsible for the care of patients after hospitalisation in the absence of home care may prolong hospitalisation and lead to the implementation of unnecessary treatment, which results in higher health care costs. The appropriate allocation of resources between the health and social care sectors and the coordination of activities between these sectors can be an effective solution. In many countries, prolonged waiting times for places in long-term care centres incurs hospital costs of maintaining additional beds. Efforts aimed at reducing care costs are based on the common health and social policy involving the distribution of financial incentives among health care providers [60].

Proposals for system solutions should also focus on improving the quality and accessibility of services offered by healthcare services provided at night and during holidays. Previous studies have proven that the patient's attendance rate to EDs correlates negatively with the availability of PHC $[1,2,13]$. However, the insufficient knowledge of patients about the role and principles 
of healthcare services provided at night and during holidays and the poor quality of services offered may contribute to the excessive use of ad-hoc care in EDs $[30,61]$. The Supreme Audit Office (2014) reports on many irregularities in the functioning of healthcare services provided at night and during holidays in Poland, such as shortening on-call time and availability for patients, understating the number of teams on duty in relation to the number contracted by the National Health Fund, not performing laboratory and X-ray tests in patients, as well as incorrectly placing information about the principles of healthcare services provided at night and during holidays [61]. In the time period examined by the Supreme Audit Office, health care was provided in clinics and centres that had a contract with the $\mathrm{Na}$ tional Health Fund. In 2017, the reform of the so-called Hospital Network was introduced. One of the purposes of this reform was to relieve EDs at weekends by locating points of healthcare services provided at night and during holidays near to the ED. Patients who report to the hospital are "taken over" by the ED staff, who makes the initial selection. Depending on the state of health, the patient is referred to the ED or to the point of healthcare service provided at night and during holidays. In Poland, there is a lack of research focused on the effectiveness of this reform. It is already known that directors of hospitals pointed to the unclear rules of admitting patients, incomplete financing and lack of money to prepare hospitals for new duties [62]. Lidal et al. conducted a systematic review to identify available research on the effects of validated triage systems for use in the pre-hospital EMS on health outcomes, patient satisfaction and patient safety. The authors concluded that there is an evidence gap regarding the effects of pre-hospital triage systems and the effects of using the same triage system in two or more settings of the Emergency Medical Service [63].

According to Oregon Primary Care Association, one of the methods which could be effective in preventing unnecessary visits to the emergency room is communicating to patients both before and after they visit the ED about after-hours care, office hours and what to do if they have an emergency [64]. A systematic review of literature conducted by Bahr et al. showed that evidence is inconclusive for the use of phone calls to decrease readmission, emergency department use, patient satisfaction and scheduled and unscheduled follow-ups [65]. Harrison et al. assessed the impact of nurse post-discharge telephone calls on 30-day hospital readmission rates. In this study, patients who received a call and completed the intervention were significantly less likely to be readmitted compared to those who did not [66]. Ismail et al. conducted a systematic review of UK and international primary care interventions to reduce inappropriate ED attendance. The researchers proved that telephone triage was the single best-evaluated intervention. This resulted in a negligible impact on ED attendance, but exhibited acceptable patient satisfaction and clinical safety [67].

Flores-Mateo et al., investigated the effectiveness of interventions consisting in providing educational guidelines to patients and supporting the development of self-care. The authors stated that the most effective is education that relates to a specific disease entity or a complex multifunctional intervention, e.g. covering health education, teaching patients how to use the health care system and social counselling [1]. In the systematic review of Morgan et al., five studies concerned the effectiveness of educational intervention in the US, but only two of them demonstrated a statistically significant impact of this education on the number of applications for EDs. In the case of interventions involving the use of brochures or conducting individual educational sessions, a reduction in the number of applications ranging from $21 \%$ to $80 \%$ was observed [68].

Patient navigation programs may be effective in prevention or in reduction of ED use. According to Valaitis et al., the main goals of patient navigation programs are: to resolve patient barriers to care, to link patients and families to PHC, specialist care and community-based health and social services, as well as to provide patient-centred care [69]. For example, Enard and Ganelin found that patient navigation intervention was associated with a decreased risk of returning to the ED among less frequent primary care-related ED users. The pre/post mean visits declined significantly over a 12-month pre/post-observation period among patients who returned to the ED for PCR reasons [70].

Winburn et al. conducted a systematic review of literature aimed at exploring the extent, focus and utilisation of telehealth for pre-hospital emergency care. The results suggest there are significant opportunities for wider diffusion of telehealth in pre-hospital care. The authors concluded that despite positive trends, telehealth utilisation in pre-hospital emergency care is fairly limited given the sheer number of EMS agencies worldwide [71]. In the study of Langabeer et al., patient care enabled by telehealth in a pre-hospital environment was more cost-effective alternative compared to the traditional EMS 'treat and transport to ED' model. The intervention consisted of telehealth-based consultation between the patients and an EMS physician to evaluate and triage the necessity for patient transport to a hospital emergency department (ED). Patients with non-urgent, primary care-related conditions were then scheduled and transported by alternative means to an affiliated primary care clinic [72]

There are also some financial incentives aimed at reducing the demand for ED services. One of them is cost sharing, defined as any kind of out-of-pocket payment for healthcare services. Cost sharing includes: co-payments (when patients pay a flat fee for each medical service sought or product purchased), co-insurance (patients pay a fixed percentage of the cost of care) and deductibles (the amount one must pay out-of-pocket annually before insurance coverage begins to pay) [30, 73]. The aim of cost sharing is to increase the individual responsibility for emergency care and discourage the use of ED services in non-life-threating situations. A breakdown of the cost of visits to emergency departments was introduced in Belgium, Finland, Italy, Ireland, Portugal and the US [2]. In a review by Morgan et al., in nine out of ten studies conducted in the US, a statistically significant reduction in the number of visits to SOR ranging from $35 \%$ to $50 \%$ was found [68].

Raven et al. evaluated 38 studies and showed that studies of ED co-payments had mixed results. In this study, only case management consistently reduced ED use. Case management programs employ case managers to assess a patient's unmet needs and to assist them by delivering care or by communicating and coordinating with health or social service agencies [74]. For example, McCormack et al. implemented a case management program within the ED that specifically focused on high ED utilisers who had alcohol dependency concerns and were homeless. Over 6 months, the median ED visit rate dropped from 18.5 to 12 [75]. Previous studies confirmed that case management seems to be successful in improving both clinical and social outcomes among frequent ED users $[30,76]$. It is worth mentioned that additional investigation is needed to determine what specific aspects of case management are the most successful and cost effective.

\section{Limitations of the study}

The strength of the study was the critical analysis of the objective statistical data obtained in the three-year follow-up. A limitation of the study was the focus on only ED and PHC indicators without taking into account the outpatient specialist care indicators. Another limitation was the analysis of data from only one ED, as well as NHF data on the functioning of the PHC in only one district. Moreover, the study included only patients reporting to the ED in non-urgent situations and focused on elderly people, without taking into account the group of patients who, for various reasons, excessively often report to the ED, i.e. 
the so-called frequent attenders. Future research should involve an analysis of outpatient specialist care data, include information from several emergency departments located in various districts and data from different NHF branches.

\section{Conclusions}

An increase in the number of ED hospitalisations in the three-year follow-up and a rise in the number of medical procedures mainly from I to III categories performed in this ward, along with a small percentage of admissions from the ED to ICU, may indirectly indicate a burden on the ED, mainly with patients reporting in non-urgent health situations.

Proposals for systemic solutions aimed at decrease the number of non-urgent visits to the ED should be based mainly on: coordinating and integrating primary health care and hospital care, improving the quality and accessibility of services offered by healthcare services provided at night and during holidays, as well as on case management and patient naviga- tion programs. There is not enough strong evidence for such interventions as co-payments or the application of telehealth for pre-hospital emergency care. It is worth considering a change in the funding mechanism of primary health care, i.e. from the current capitation system into a mixed system in order to better motivate primary health care doctors to act as gatekeepers of the health care system, take full care over patients and prevent the phenomenon of "pushing" them to outpatient specialist care facilities and hospital wards. The financing of PHC in a mixed system should be based on combining the capitalisation fee with elements of a fee for the service provided, as well as on the payment of bonuses for achieving specific care effects. The development of constructive solutions for the ED and PHC should be based on periodic monitoring of the level of patient satisfaction along with the quality of services provided by PHC, checking the satisfaction of primary care physicians with methods of PHC funding they prefer, systemic solutions proposed by doctors themselves and controlling the level of coordination of services between the ED and PHC.

Source of funding: This work was funded from the authors' own resources.

Conflicts of interest: The authors declare no conflicts of interest.

\section{References:}

1. Flores-Mateo G, Violan-Fors C, Carillo-Santisteve P, et al. Effectiveness of organizational interventions to reduce emergency department utilization: a systematic review. PLOS ONE 2012; 7(5): e35903, doi: 10.1371/journal.pone.0035903.

2. Berchet C. Emergency Care Services: Trends, Drivers and Interventions to Manage the Demand, OECD Health Working Papers, 2015 No. 83, OECD Publishing, Paris [serial online] [cited 19.11.2017]. Available from URL: http://dx.doi.org/10.1787/5jrts344crns-en.

3. Pines JM, Hilton JA, Weber EJ, et al. International perspectives on emergency department crowding. Acad Emerg Med 2011; 18(12): 1358-1370.

4. Bjørnsen LP, Uleberg O, Dale J. Patient visits to the emergency department at a Norwegian university hospital: variations in patient gender and age, timing of visits, and patient acuity. Emerg Med J 2013; 30(6): 462-466.

5. Rocovich C, Patel T. Emergency department visits: why adults choose the emergency room over a primary care physician visit during regular office hours? World J Emerg Med 2012; 3(2): 91-97.

6. Sarver JH, Cydulka RK, Baker DW. Usual source of care and non-urgent emergency department use. Acad Emerg Med 2002; 9: 916-923.

7. Yarmohammadian MH, Rezaei F, Haghshenas A, et al. Overcrowding in emergency departments: a review of strategies to decrease future challenges. J Res Med Sci 2017; 22: 23, doi: 10.4103/1735-1995.200277.

8. Statement on Emergency Department Overcrowding. Australasian college for emergency medicine 2011; Jul 16: 57 [cited 13.11.2017]. Available from URL: https://acem.org.au/getattachment/0789ef2f-d814-4e86-af81-aad8b9e57c6d/Statement-on-Emergency-Department-Overcrowding.aspx.

9. Tekwani KL, Kerem Y, Mistry CD, et al. Emergency Department Crowding is associated with reduced satisfaction scores in patients discharged from the emergency department. West J Emerg Med 2014; 14(1): 11-15.

10. Filippatos G, Evridiki K. The effect of Emergency department crowding on patient outcomes. Health Science Journal $2015 ; 9(16): 1-6$.

11. Kulstad EB, Kelley KM. Overcrowding is associated with delays in percutaneous coronary intervention for acute myocardial infarction. Int J Emerg Med 2009; 2(3): 149-154, doi: 10.1007/s12245-009-0107-x.

12. Sun BC, Hsia RY, Weiss RE, et al. Effect of emergency department crowding on outcomes of admitted patients. Ann Emerg Med 2012; 61(6): 605-611.

13. Berchet C. Emergency Care Services: trends, drivers and interventions to manage the demand, OECD health working papers, 2015 No. 83, OECD Publishing, Paris [serial online] [cited 19.11. 2017]. Available from URL: http://dx.doi.org/10.1787/5jrts344crns-en.

14. Guła P, Kutaj-Wąsikowska H, Kalinowski M. A model of emergency department throughput in Poland. J Orthop Trauma Surg Rel Res 2012; 4: 31-37.

15. Ondler C, Hegde GG, Carlson JN. Resource utilization and health care charges associated with the most frequent ED users. Am J Emerg Med 2014; 32(10): 1215-1219.

16. Bieler G, Paroz S, Faouzi M, et al. Social and medical vulnerability factors of emergency department frequent users in a universal health insurance system. Acad Emerg Med 2012; 19(1): 63-68.

17. LaCalle E, Rabin E. Frequent users of emergency departments: the myths, the data, and the policy implications. Ann Emerg Med 2010; 56(1): 42-48.

18. Doupe MB, Palatnick W, Day S, et al. Frequent users of emergency departments: developing standard definitions and defining prominent risk factors. Ann Emerg Med 2012; 60(1): 24-32.

19. Quilty $S$, Shannon G, Yao A, et al. Factors contributing to frequent attendance to the emergency department of a remote Northern Territory hospital. Med J Aust 2016; 204(3): 111.

20. Brennan JJ, Chan T, Hsia RY, et al. Emergency department utilization among frequent users with psychiatric visits. Acad Emerg Med 2014; 21(9): 1015-1022.

21. Gentile $\mathrm{S}$, Vignally $\mathrm{P}$, Durand $\mathrm{AC}$, et al. Nonurgent patients in the emergency department? A French formula to prevent misuse. $B M C$ Health Serv Res 2010; 10: 66, doi: 10.1186/1472-6963-10-66.

22. $\mathrm{Ng} \mathrm{CJ}$, Liao PJ, Chang YC, et al. Predictive factors for hospitalization of nonurgent patients in the emergency department. Medicine (Baltimore) 2016; 95(26): e4053, doi: 10.1097/MD.0000000000004053.

23. McHale $\mathrm{P}$, Wood $\mathrm{S}$, Hughes $\mathrm{K}$, et al. Who uses emergency departments inappropriately and when - a national cross-sectional study using a monitoring data system. BMC Med 2013; 11: 258, doi: https://doi.org/10.1186/1741-7015-11-258.

24. Durand AC, Gentile S, Devictor B, et al. ED patients: how nonurgent are they? Systematic review of the emergency medicine literature. Am J Emerg Med 2011; 29: 333-345. 
25. Gulacti U, Lok U, Celik M, et al. The ED use and non-urgent visits of elderly patients. Turk J Emerg Med 2016; 16(4): 141-145, doi: 10.1016/j.tjem.2016.08.004.

26. Wise J. Most emergency attendances at hospital are appropriate, finds study. BMJ 2014; 348: g3479, doi: https://doi.org/10.1136/ bmj.g3479.

27. Uscher-Pines L, Pines J, Kellermann A, et al. Deciding to visit the Emergency Department for non-urgent conditions: a systematic review of the literature. Am J Manag Care 2013; 19(1): 47-59.

28. Najwyższa Izba Kontroli. Funkcjonowanie Systemu Ratownictwa Medycznego. Informacja o wynikach kontroli. Nr ewidencyjny 149/2012/P11094/KZD [serial online] [cited 13.11.2017]. Available from URL: https://www.nik.gov.pl/kontrole/wyniki-kontroli-nik/ kontrole,10324.html (in Polish).

29. Karawan K, Guła P. Ocena zasadności stosowania szpitalnej segregacji medycznej w aspekcie bezpieczeństwa pacjentów leczonych w Szpitalnym Oddziale Ratunkowym. Lek Wojsk 2013; 4: 395-398 (in Polish).

30. Van den Heede K, Van de Voorde C. Interventions to reduce emergency department utilization: a review of reviews. Health Policy 2016; 120(12): 1337-1349.

31. Banerjee J, Conroy S. Quality care for older people with urgent and emergency care needs. London: British Geriatrics Society, 2012 [serial online] [cited 06.07.2017]. Available from URL: http://www.bgs.org.uk/campaigns/silverb/silver_book_complete.pdf.

32. Blunt I, Bardsley M, Dixon J. Trends in emergency admissions in England 2004-2009: is greater efficiency breeding inefficiency? London: Nuffield Trust 2010 [serial online] [cited 06.07.2017]. Available from URL: https://www.nuffieldtrust.org.uk/research/trends-inemergency-admissions-in-england-2004-2009.

33. Eurostat Statistics Explained. Population structure and aging [serial online] [cited 03.01.2019]. Available from URL: https://ec.europa. eu/eurostat/statistics-explained/index.php/Population_structure_and_ageing\#the_share_of_elderly_people_continues_to_increase.

34. Stańczak J, Szałtys D. Regionalne zróżnicowanie procesu starzenia się ludności Polski w latach 1990-2015 oraz w perspektywie do 2040 roku [cited 03.01.2019]. Available from URL: https://stat.gov.pl/files/gfx/portalinformacyjny/pl/defaultaktualnosci/5468/28/1/1/regionalne_zroznicowanie_procesu_starzenia_sie_ludnosci.pdf (in Polish).

35. Azuma K, Ohta S. Relations with emergency medical care and primary care doctor, home health care. Nihon Rinsho 2016; 74(2): 203-214.

36. Fedorowski JJ. Ratunkowe, czy od wszystkiego. Menedżer Zdrowia 2016; 1: 12-20 (in Polish).

37. Tsai JC, Liang YW, Pearson WS. Utilization of emergency department in patients with non-urgent medical problems: patient preference and emergency department convenience. J Formos Med Assoc 2010; 109(7): 533-542.

38. Durand A-C, Palazzolo S, Tanti-Hardouin N, et al. Nonurgent patients in emergency departments: rational or irresponsible consumers? Perceptions of professionals and patients. BMC Research Notes 2012; 5: 525, doi: 10.1186/1756-0500-5-525.

39. Aller MB, Vargas I, Coderch J, et al. Doctors' opinion on the contribution of coordination mechanisms to improving clinical coordination between primary and outpatient secondary care in the Catalan national health system. BMC Health Serv Res 2017; 17(1): 842, doi: 10.1186/s12913-017-2690-5.

40. Carrier E, Yee T, Holzwart RA. Coordination between emergency and primary care physicians. NIHCR 2011; 3: 1-11.

41. Polska w liczbach. Powiat kędzierzyńsko-kozielski w liczbach [serial online] [cited 26.12.2018. Available from URL: http://www.polskawliczbach.pl/powiat_kedzierzynsko_kozielski (in Polish).

42. Health and Health Care in 2014. Central Statistical Office. Social Surveys and Living Conditions Department. Warsaw 2015 [serial online] [cited 10.02.2019]. Available from URL: http://www.stat.gov.pl/.

43. Health and Health Care in 2015. Central Statistical Office. Social Surveys and Living Conditions Department. Warsaw 2016 [serial online] [cited 10.02.2019]. Available from URL: http://www.stat.gov.pl/.

44. Health and Health Care in 2017. Central Statistical Office. Social Surveys and Living Conditions Department. Warsaw 2018 [serial online] [cited 10.02.2019]. Available from URL: http://www.stat.gov.pl/.

45. Health and Health Care in 2012. Central Statistical Office. Social Surveys and Living Conditions Department. Warsaw 2013 [serial online] [cited 10.02.2019]. Available from URL: http://www.stat.gov.pl/.

46. Health and Health Care in 2013. Central Statistical Office. Social Surveys and Living Conditions Department. Warsaw 2014 [serial online] [cited 10.02.2019]. Available from URL: http://www.stat.gov.pl/.

47. Barometr WHC. Raport na temat zmian w dostępności do gwarantowanych świadczeń zdrowotnych w Polsce nr 15/3/12/2016 [serial online] [cited 20.09.2017]. Available from URL: http://www.korektorzdrowia.pl/wp-content/uploads/barometrwhc_xv.final_-2.pdf (in Polish).

48. Guła P, Karawan K. Wykorzystanie analizy Lean do oceny funkcjonowania Szpitalnych Oddziałów Ratunkowych na podstawie doświadczeń własnych. Lek Wojsk 2012; 90(3): 1-4 (in Polish).

49. Bardford C, Lauritzen MM, Danker JK, et al. The information and design of the acute admission database - a database including a prospective, observational cohort of 62789 patients triaged in the Emergency Department in a larger Danish hospital. Scend J Trauma Resusc Emerg Med 2012; 20: 29, doi: 10.1186/1757-7241-20-29.

50. Centers for Disease Control and Prevention. National Hospital Ambulatory Medical Care Survey: 2011 Emergency Department Summary Tables [serial online] [cited 08.10.2018]. Available from URL: http://www.cdc.gov/nchs/data/ahcd/nhamcs_emergency/2011_ ed_web_tables.pdf.

51. Centers for Disease Control and Prevention. National Hospital Ambulatory Medical Care Survey: 2015 Emergency Department Summary Tables [serial online] [cited 08.10.2018]. Available from URL: https://www.cdc.gov/nchs/data/ahcd/nhamcs_emergency/2011_ ed_web_tables.pdf.

52. Borek E, Kilijanek-Cieślik A, Perendyk T, et al. Jaką podstawową opiekę zdrowotną mamy a jakiej potrzebujemy? Wyniki sondażu opinii pacjentów i obywateli [serial online] [cited 13.11.2017]. Available from URL: http://razemdlazdrowia.pl/konsultacje/1-jakiego-pozpotrzebujemy (in Polish).

53. Baranowski J, Windak A. Optymalizacja polskiego systemu finansowania podstawowej opieki zdrowotnej. Sprawne Państwo. Program Ernst \& Young. Warszawa 2012 [serial online] [cited 12.07.2017]. Available from URL: http://www.ey.com/Publication/vwLUAssets/ Sprawne Panstwo Optymalizacja_POZ/\$FILE/Sprawne-Panstwo-Optymalizacja-POZ-05092012.pdf (in Polish).

54. Borek E, Brzeziński M, Sitek A, et al. Mechanizm finansowania a stopień realizacji standardu opieki profilaktycznej nad dziećmi w wieku 0-5 lat. Analiza jakości profilaktycznej opieki pediatrycznej w świetle danych Narodowego Funduszu Zdrowia, Centrum Systemów Informatycznych w Ochronie Zdrowia oraz oceny rodziców. Stand Med, Pediatr 2017; 14: 335-343 (in Polish).

55. Kowalska K, Kalbarczyk WP. Koordynowana opieka zdrowotna. Doświadczenia międzynarodowe, propozycje dla Polski. Warszawa: Sprawne Państwo. Program EY; 2013: 92 (in Polish).

56. McDonald KM, Sundaram V, Bravata DM, et al. Closing the Quality Gap: A Critical Analysis of Quality Improvement Strategies, Volume 7. Care Coordination. Rockville, MD: Agency for Healthcare Research and Quality, U.S. Department of Health and Human Services; 2007. 
57. Penm J, MacKinnon NJ, Strakowski SM, et al. Minding the Gap: factors associated with primary care coordination of adults in 11 countries. Ann Fam Med 2017; 15(2): 113-119.

58. Thijssen WAMH, Wijnen-van Houts M, Koetsenruijter J, et al. The impact on emergency department utilization and patient flows after integrating with a general practitioner cooperative: an observational study. Emerg Med Int 2013; 364-659.

59. Rider AC, Kessler CS, Schwarz WW, et al. Transition of care from the emergency department to the outpatient setting: a mixed-methods analysis. West J Emerg Med 2018; 19(2): 245-253.

60. OECD. Tackling Wasteful Spending on Health, OECD Publishing, Paris 2017 [serial online] [cited 19.11.2017]. Available from URL: http:// dx.doi.org/10.1787/9789264266414-en.

61. Raport NIK. Dostępność świadczeń nocnej i świątecznej opieki zdrowotnej. Informacja o wynikach kontroli. Nr ewid. 1/2014/P/13/129/ KZD [cited 26.05.2019]. Available from: https://www.nik.gov.pl/plik/id,6459,vp,8230.pdf (in Polish).

62. Medonet. Rewolucja na SOR-ach i w nocnej opiece zdrowotnej. Co się zmieni? [serial online] [cited 12.12.2019]. Available from URL: http://www.medonet.pl/zdrowie,rewolucja-na-sor-ach-i-w-nocnej-opiece-zdrowotnej-co-sie-zmieni-,artykul,1723776.html (in Polish).

63. Lidal IB, Holte HH, Vist GE. Triage systems for pre-hospital emergency medical services - a systematic review. Scand J Trauma Resusc Emerg Med 2013; 21: 28. doi: 10.1186/1757-7241-21-28.

64. Emergency Department Utilization. Oregon Primary Care Association [serial online] [cited 15.02.2019]. Available from URL: https:// www.orpca.org/initiatives/dtp/shared-strategies-best-practices/emergency-department-utilization.

65. Bahr SJ, Solverson S, Schlidt A, et al. Integrated literature review of postdischarge telephone calls. West J Nurs Res 2014; 36(1): 84-104, doi: 10.1177/0193945913491016.

66. Harrison JD, Auerbach AD, Quinn K, et al. Assessing the impact of nurse post-discharge telephone calls on 30-day hospital readmission rates. J Gen Intern Med 2014; 29(11): 1519-1525.

67. Ismail SA, Gibbons DC, Gnani S. Reducing inappropriate accident and emergency department attendances: a systematic review of primary care service interventions. Br J Gen Pract 2013; 63: e813-e820.

68. Morgan SR, Chang AM, Alqatari M, et al. Non-emergency department interventions to reduce ED utilization: a systematic review. Acad Emerg Med 2013; 20: 969-985.

69. Valaitis RK, Carter N, Lam A, et al. Implementation and maintenance of patient navigation programs linking primary care with community-based health and social services: a scoping literature review. BMC Health Serv Res 2017; 17(1): 116, doi: 10.1186/s12913017-2046-1.

70. Enard KR, Ganelin DM. Reducing preventable emergency department utilization and costs by using community health workers as patient navigators. J Healthc Manag 2013; 58(6): 412-427.

71. Winburn AS, Brixey JJ, Langabeer J 2nd, et al. A systematic review of prehospital telehealth utilization. J Telemed Telecare 2018; 24(7): 473-481, doi: 10.1177/1357633X17713140.

72. Langabeer JR 2nd, Champagne-Langabeer T, Alqusairi D, et al. Cost-benefit analysis of telehealth in pre-hospital care. J Telemed Telecare 2017; 23(8): 747-751, doi: 10.1177/1357633X16680541.

73. Health Caregov. Individuals and families. Small business. [cited 11.07.2017]. Available from URL: https://www.healthcare.gov/glossary/deductible/.

74. Raven MC, Kushel M, Ko MJ, et al. The effectiveness of emergency department visit reduction programs: a systematic review. Ann Emerg Med 2016; 68(4): 467-483, doi: 10.1016/j.annemergmed.2016.04.015.

75. McCormack RP, Hoffman LF, Wall SP, et al. Resource-limited, collaborative pilot intervention for chronically homeless, alcohol dependent frequent emergency department users. Am J Public Health 2013; 103(Suppl.): S221-S224.

76. Kumar GS, Klein R. Effectiveness of case management strategies in reducing emergency department visits in frequent user patient populations: a systematic review. J Emerg Med 2013; 44(3): 717-729.

Tables: 2

Figures: 0

References: 76

Received: 16.01.2019

Reviewed: 29.01 .2019

Accepted: 16.02 .2019

Address for correspondence:

Katarzyna Szwamel, PhD

Państwowa Medyczna Wyższa Szkoła Zawodowa

ul. Katowicka 68

45-060 Opole

Polska

Tel.: +48 605 513-431

E-mail: k.szwamel@interia.pl 